\title{
THE PRESUMED EXTINCT ARGENTIPALLIUM SPICERI (ASTERACEAE) REDISCOVERED IN TASMANIA
}

\author{
by Alex M. Buchanan
}

(with one text-figure and one plate)

Buchanan, A.M., 1998 (31:xii): The presumed extinct Argentipallium spiceri (Asteraceae) rediscovered in Tasmania. Pap. Proc. R. Soc. Tasm. 132: 71-73. ISSN 0080-4703. https://doi.org/10.26749/rstpp.132.71 Tasmanian Herbarium, GPO Box 252-4, Hobart, Tasmania, Australia 7001.

The presumed extinct shrub Argentipallium spiceri (Asteraceae) has been rediscovered at the edge of Eucalyptus obliqua forest in southeastern Tasmania. Notes on its history, distribution and ecology are presented.

Key Words: Argentipallium spiceri, threatened species, Tasmania.

\section{INTRODUCTION}

Argentipalliumspiceriwas first collected by Augustus Simson from "the roadside, going from Longley towards the Sandfly coal seam" (Simson 1880). He found only one individual and gathered material from it over two successive summers, in December 1876 and January 1878. It was recognised as an undescribed species of Helichrysum, and a brief mention of its existence was made as an addendum in the Reverend William Spicer's Handbook of the Plants of Tasmania, published soon after the discovery (Spicer 1878). A portion of the material was sent to Ferdinand von Mueller in Melbourne who described it as Helichrysum spiceri (Mueller 1878). Subsequently, Rodway (1903) considered it to be conspecific with $H$. obtusifolium but Curtis (1963) reinstated it as a separate species. More recently, as part of a revision of the genus Helichrysum in Australia, Wilson (1992) transferred the taxon to the newly erected genus Argentipallium.

Until the present, only two further gatherings of this plant were known. Three sheets from the Rodway herbarium variously bear the location and date "Huonville" and "January 1892" and a gathering by W.M. Curtis from the Huon Highway near Scotts Road, south of Geeveston, is dated " 4 Dec 1958". The known distribution is shown in figure 1 . The species was presumed to be extinct (Briggs \& Leigh 1995) and listed as such in the Threatened Species Protection Act (Tasmania), Schedule 3, Part 2 (1995).

In November 1997, a specimen of a shrub, growing as a wildling, not cultivated, in a bush garden that merges into the forest, about $12 \mathrm{~km}$ southwest of Hobart was forwarded to the Tasmanian Herbarium for identification. The specimen was identified as Argentipallium spiceri, and this determination was confirmed following comparison with the holotype held at MEL.

\section{METHODS AND MATERIALS}

Material from the rediscovered plant was compared with the holotype held at MEL. All known herbarium specimens in Australia were located and examined (except BRI). Abbreviations of herbaria cited follow Holmgren et al. (1990). Field notes were made at known collection sites and species nomenclature follows Buchanan (1995).

\section{DESCRIPTION}

Argentipallium spiceri (F. Muell.) Paul G. Wilson,1992 Nuytsia 8(3), 1992: 458

1878 Helichrysum spiceri F. Muell., Fragm. 11: 47.

1878 Helichrysum sp. Spicer, A Handbook of the Plants of Tasmania: 149.

1963 Curtis, The Student's Flora of Tasmania 2: 329.

Type: [Tasmania] near Longley, 12 January 1878, Simson 824.

Holotype: MEL!

Isotypes: HO!, Queen Victoria Museum, Launceston!

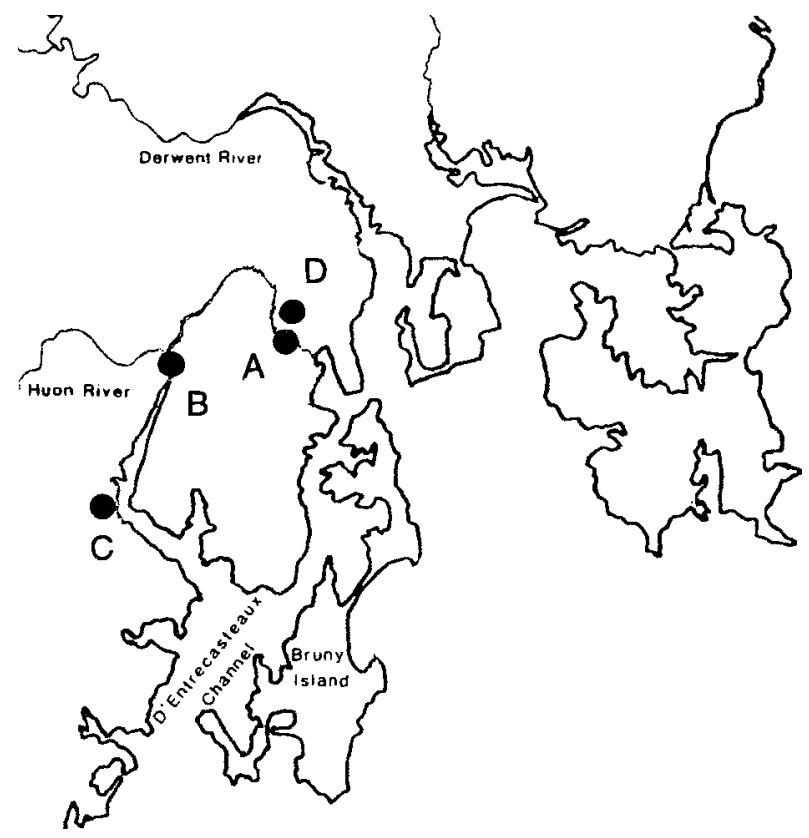

FIG. 1 - Location of the four known occurrences of Argentipallium spiceri. A - Longley; $B$ - Huonville; $C-$ Scotts Road, Cairns Bay; D-Leslie Vale. 
Small, sparingly branched shrub to about $0.9 \mathrm{~m}$ tall. Branches slender and often lax, in some cases drooping when in flower, with a covering of long, appressed, fine, silky white hairs. Leaves linear, entire and mostly 10-15 $\mathrm{mm}$ long and $2-3 \mathrm{~mm}$ wide; base attenuate; apex with a small brown mucro; upper surface green, smooth to finely hispid; lower surface with a dense covering of felted, fine white to grey or very pale brown tomentum. Inflorescence a terminal panicle with up to six main branches; capitula 1-25, 10-15 mm diam; involucral bracts conspicuous, 5$6 \mathrm{~mm}$ long, brown and pink at the base (turning brown with age), white towards the apex, colourless below the middle; shorter, outer involucral bracts totally pink and sometimes with darker pink striations near the apex. Florets $3 \mathrm{~mm}$ long, with pappus to $4 \mathrm{~mm}$ long; achenes cylindrical, $0.8-1 \mathrm{~mm}$ long, $0.3 \mathrm{~mm}$ wide, with scattered, short, appressed hairs. (Pl. 1.)

\section{OBSERVATIONS ON THE TYPE MATERIAL AND RELATED SHEETS}

Three sheets of type material are known to exist in Australia. The holotype in MEL bears a label in Simson's handwriting: "824. Helichrysum? nr Longley, 12 Jan 1878. I got this two successive summers; I saw but one plant, shrubby \& bushy \& got a lot of specimens each time", and has been annotated by Mueller. This makes it clear that the type material is from the second gathering.

There is an isotype in HO marked "Longley 1878" and inscribed "L. Rodway exchange with A[ugustus] S[imson]" in the handwriting of Janet Somerville who was caretaker of the Tasmanian Herbarium in the 1950s (Parham 1976). Having been part of Rodway's herbarium, the sheet was filed under Helichrysum obtusifolium.

A further isotype is held at the Queen Victoria Museum, Launceston, Tasmania. It is a small flowering specimen labelled "Longley, January 1878".

Another sheet in MEL, from Spicer's herbarium, is undated and unclearly numbered 26 or 36 ; it may be an isotype but has insufficient details to be certain.
A sheet in BRI bears the inscription in Simson's handwriting "36. Helichrysum Spiceri Mueller nr. Longley, new species found by myself - no one else ever found it. Is a shrubby plant". "A. Simson, Launceston" has been written in another hand. There is no date, and whether it is a type is, therefore, uncertain. The specimen is a single, small, flowering branchlet.

The whereabouts of Simson's other specimens is unknown. Many of Simson's duplicates of other material were included in the Spicer Herbarium when it was purchased by Michel Gandoger about 1890 and are now in LYON, in France (McGillivray 1973). However, despite a thorough search in the collection at LYON, no Argentipallium spiceri was found (Gaëtan Guignard, pers. comm.).

\section{NOTES}

Argentipallium spiceri is recognised by its multiple-headed inflorescence (pl. 1A) with conspicuous involucral bracts and by its open, branching habit and small leaves (pl. 1B). As a shrubby member of the genus Argentipallium, it most closely resembles $A$. obtusifolium, a species that, in Tasmania, is confined to the islands of the Furneaux group in Bass Strait. A third Tasmanian species of Argentipallium, $A$. dealbatum, is a widespread, perennial, herbaceous plant common in open, dry habitats. $A$. spiceri differs from both of these species in having a compound inflorescence with up to about 25 heads. Non-flowering plants might be mistaken for small specimens of Cassinia aculeata or Ozothamnus ferrugineus, both of which grow in the same area as the recently rediscovered plant.

There is considerable variation in morphological characters between the four collections. The 1892 collection differs from the type in having paler green leaves with a white (rather than brownish) indumentum on the underside and with a longer, paler mucro. The 1958 collection is even more different. It is a smaller, more compact plant and much more densely leafy. The leaves are grey, sparsely tomentose or sometimes hispid on the upper surface and are densely tomentose on the lower side. The panicles are
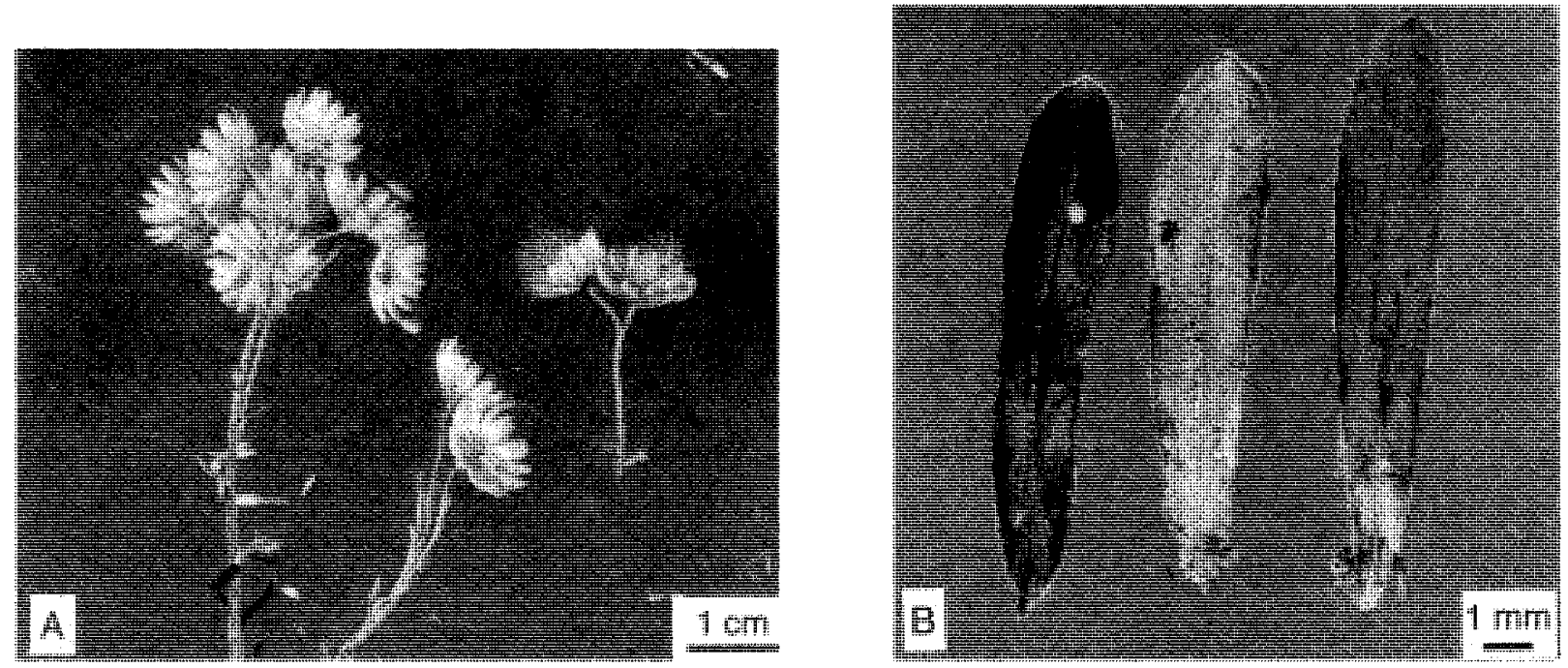

PLATE 1

Inflorescence $(A)$ and leaves (B) of Argentipallium spiceri. 
more compact and terminate clustered axillary shoots as well as the main axes.

The recently discovered plant reported in this paper is a sparingly branched, open shrub, with slender branches drooping when in flower, promoting the growth of small, lateral shoots. The leaves are grey-green and scabrid on the upper surface and white tomentose below.

\section{LOCATION AND ECOLOGY}

The site of Augustus Simson's original, single plant, found in 1876, is difficult to locate. Although the village of Sandfly is only $1 \mathrm{~km}$ south of Longley, the Sandfly coal seam that he refers to is at Kaoota (Bacon 1991), a further $5 \mathrm{~km}$ to the south. Mining was already in progress there by 1877 (Anon. 1877). The geology varies from sandstone between Longley and Sandfly to mostly dolerite south of Sandfly. Nevertheless, almost all of the forest in this area is dominated by Eucalyptus obliqua.

The 1892 collection by L. Rodway cannot be precisely located. The stated locality, Huonville, a small town, is probably given as simply the nearest named place. Rodway also notes that it is a "much branched straggling undershrub ...", inferring a forest or woodland habitat.

The 1958 collection by W.M. Curtis, although not precisely located on the label, was almost certainly collected about 100 to $200 \mathrm{~m}$ southeast of the intersection of Scotts Road with the Huon Highway, between Geeveston and Waterloo (M. Allan, pers. comm., and on-site discussion with W.M. Curtis, March 1998). This area is dominated by $E$. obliqua open forest with scattered trees of $E$. ovata on dolerite. The habitat was described as "dry bank - roadside".

The newly discovered location at Leslie Vale is on the edge of E. obliqua forest, where it grades into drier $E$. pulchella and E. viminalis open forest or woodland at the crest of a gentle, south-facing slope. The understorey is open, with scattered Banksia marginata, Bedfordia salicina, Exocarpos cupressiformis, Leptospermum scoparium and Pultenaea juniperina and with clumps of Lomandra longifolia and Diplarrena moraea. The underlying rock is dolerite with a shallow, rocky, clay soil. The soil on which the plant is growing was disturbed about ten years ago.

\section{OTHER SPECIMENS EXAMINED}

Longley, Huon Road, s.d., A. Simson 36 [or 26] (ex herb. Spicer)(MEL 2042930); nr. Longley, s.d., A. Simson 36 (BRI) [facsimile only seen]; Huonville, Jan 1892, L. Rodway 392a (HO 12691); Huonville, s.d., L. Rodway 392a (HO 12690); Huonville, s.d., L. Rodway s.n. (HO 12692); near Scotts Rd turnoff, Cairns Bay, Huon Highway, 4 Dec 1958 , W.M. Curtis s.n. (HO 52623); Leslie Vale, Nov 1997, P.J. Eberhards.n. (HO 323423); Leslie Vale, 13 Feb 1998, A.M. Buchanan 15085 (HO 324666).

\section{ACKNOWLEDGEMENTS}

Particular thanks are due to Jo Eberhard as the discoverer of the rare plant and for allowing unhindered access to her property during the months that followed. The directors of LYON, NT, BRI, NSW, CANB, AD, PERTH, MEL and Queen Victoria Museum kindly checked their holdings for material. The latter two made specimens available. Monika Wells kindly searched the database of the Mueller Correspondence Project. I also thank Gintaras Kantvilas for his comments on earlier drafts of the manuscript. Andrew Rozefelds provided the photographic expertise.

\section{POSTSCRIPT}

A search of the area surrounding the rediscovered plant has not been successful in locating further individuals (A.M. Gray, pers. comm.). Propagation by cuttings has been successful but seed germination has not, there apparently being no viable seed (N. Papworth, pers. comm.).

\section{REFERENCES}

ANON., 1877: House of Assembly (Tas.) Journal 33: 25.

BACON, C.A., 1991: The coal resources of Tasmania. Bull. Geol. Surv. Tasm. 64: 106-108.

BRiggs, J.D. \& LEIGH, J.H., 1995: RARE OR THREATENED AUSTRALIAN PLANTS. CSIRO, Canberra.

BuChanan, A.M., 1995: A Census of the Vascular Plants of Tasmania \& Index to The Student's Flora of Tasmania. Tasm. Herb. Occ. Publ. 5.

CURTIS, W.M., 1963: THE STUDENT'S FLORA OF TASMANIA. Part 2. Government Printer, Hobart.

Holmgren, P.K., Holmgren, N.H. \& BarnetT, L.C., 1990: INDEX HERBARIORUM. New York Botanical Garden, USA.

MCGiluivraY, D.J., 1973: Michel Gandoger's names of Australian plants. Contr. N.S.W. Natl Herb. 4(6): 319-365.

Mueller, F., 1878: Helichrysum Spiceri. Fragmenta Phytographiae Australiae 11: 47-48.

PARHAM, J.W., 1976: ABRS Tasmanian Herbarium Project Final Report. Unpubl. rep.

RODWAY, L., 1903: THE TASMANIAN FLORA. Government Printer, Hobart.

Simson, A., 1880: On recent additions to the flora of Tasmania. Pap. Proc. R. Soc. Tasm. 1879: 43.

SPICER, W.W., 1878: A HANDBOOK OF THE PLANTS OF TASMANLA. J.Walch and Sons, Hobart.

WiLson, P.G., 1992: The classification of some Australian species currently included in Helipterum and Helichrysum (Asteraceae: Gnaphalieae): Part 3 Anemocarpa and Argentipallium, two new genera from Australia. Nuytsia 8 (3): 447-60

(accepted 11 August 1998) 